\title{
Metallic materials for medical use
}

\author{
Anatoly Illarionov ${ }^{1}$, Sergey Belikov ${ }^{1}$, Stella Grib $^{1, *}$, and Artem Yurovskikh ${ }^{1}$ \\ ${ }^{1}$ Ural Federal University named after the first President of Russia B.N. Yeltsin, Russian Federation
}

\begin{abstract}
This article provides a brief overview of the metallic materials used as implants in orthopedics, the alloying system and a complex of the physical-mechanical properties for metallic materials certified for medical use, as well as the advantages and drawbacks of using metallic materials as implants. Approaches to improve the quality of an implant made of metallic materials are noted.
\end{abstract}

\section{1 introduction}

According to the Hench and Polak classification [1], metals and their alloys refer to inert biomaterials of the "first generation". It is necessary to take into account the conventionality of this classification, since the materials of the "second" (biologically active and biodegradable polymers and ceramics [2]) and the "third" (materials aimed to achieve certain cellular responses on the molecular level, for example, composite materials [2]) are not intended to replace previously created materials; their purpose is to create qualitatively new, improved methods of therapy. The use of more expensive biomaterials and the complication of their production, as in the case of composites, significantly increase financial costs, which in turn limit the commercial availability of the most advanced medical technologies. Therefore, the use of financially feasible solutions using traditional biomaterials, in particular metal, remains relevant even now, especially in the field of hard tissue restoration.

\section{Metallic materials in orthopedics}

"Biomaterial" usually means any material intended to partially or completely replace and perform the function of an organ or tissue of a living organism [3]. Therefore, two main applications of biomaterials are distinguished in orthopedics: the replacement (augmentation) of defects in bone tissue, for example, in the treatment of fractures; replacement and reconstruction of the musculoskeletal system, such as joints, ligaments, intervertebral disks, resected bone fragments. In the latter case, metal materials have found wide application in medicine as bone fixing devices and prosthetic studs [4].

The common biomaterials used in orthopedic surgery can be divided into two groups [5]: metals and non-metals (polymers, ceramics, etc.). One of the important characteristics for materials used as implants are high strength and resistance to fatigue failure, and the modulus of elasticity close to the modulus of elasticity of the human bone. Polymers, despite their lightness, manufacturability, flexibility and low modulus, are highly prone to creep, which can lead to a $20 \%$ weakening of the initial retaining force of the polymer screws and, as a consequence, the mobility of the implant [6]. In case of alternating loads, polymers often fails at stress levels even below the fatigue limit $\left(\sigma_{-1}\right)$ of bone tissue (see Table 1$)$. The main disadvantage of ceramics is their low tensile and flexural strength, as a result, they shows brittle fracture under cyclic loads. Usually, metal materials have high strength characteristics (yield strength $\sigma_{0.2}$ and temporary failure resistance (ultimate strength) $\left.\sigma_{\mathrm{B}}\right)$ and high fatigue resistance $\left(\sigma_{-1}\right)$ in comparison with ceramics and polymers (see Table 1), and therefore, at present time more than $60 \%$ of all implants are made of metallic materials [7]. Metal materials such as stainless steel, cobalt-based alloys, titanium and its alloys are used in orthopedic surgery nowadays. Some of the physical and mechanical properties that can be obtained by means of heat and mechanical treatment for certified for medical use metallic materials are given in Table 1 compared to the properties of bone, polymers and ceramics.

A number of advantages of titanium alloys can be noted compared to other metallic materials. According to their strength characteristics, titanium alloys are not inferior to cobalt-based alloys and stainless steel, while their specific strength $\left(\sigma_{\mathrm{B}} / \rho\right)$ can exceed them. Thus, according to Table 1, the maximum specific strength is $17.3 \mathrm{~km}$ for stainless steel, $23.2 \mathrm{~km}$ for cobalt-based alloys and $29.2 \mathrm{~km}$ for titanium-based alloys. Moreover, titanium-based alloys exhibit a much lower elastic modulus E (50$121 \mathrm{GPa}$ ) compared to other metal alloys, such as stainless steel (190-230 GPa) and cobalt-based alloys (200-541 GPa), indicating a better mechanical compatibility of titanium alloys with a bone with less than $30 \mathrm{GPa}$ elastic modulus.

It should be noted that the most obvious drawbacks of both stainless steels and (Co, Mo, Cr)

\footnotetext{
* Corresponding author: s.v.grib@urfu.ru
} 
Table 1. Some of the physical and mechanical properties of bone, nonmetallic and metallic materials used in orthopedics

\begin{tabular}{|c|c|c|c|c|c|c|c|}
\hline \multirow{3}{*}{$\begin{array}{c}\text { Material (alloying } \\
\text { system) }\end{array}$} & \multirow{2}{*}{\multicolumn{2}{|c|}{ Standards }} & \multicolumn{5}{|c|}{ Properties } \\
\hline & & & \multicolumn{2}{|c|}{ Physical } & \multicolumn{3}{|c|}{ Mechanical $^{1}$} \\
\hline & ASTM & ISO & $\mathrm{E}, \mathrm{GPa}$ & $\rho, \mathrm{kg} / \mathrm{m}^{3}$ & $\sigma_{0,2}, \mathrm{MPa}$ & $\sigma_{\mathrm{B}}, \mathrm{MPa}$ & $\begin{array}{c}\sigma_{-1}, \mathrm{MPa} \\
\left(10^{7} \text { cycles }\right)\end{array}$ \\
\hline \multicolumn{8}{|l|}{ Bone tissue } \\
\hline Cortical & - & - & $15-23,8^{[8]}$ & $1800-2000^{[9]}$ & $114-129^{[8]}$ & $68-157^{[8]}$ & $30-78^{[10,11]}$ \\
\hline Trabecular & - & - & $0,17^{[8]}$ & $100-1500^{[9]}$ & & $3,85^{[8]}$ & \\
\hline \multicolumn{8}{|l|}{ Polymers $^{[10]}$} \\
\hline UHMWPE & - & - & $0,5-1,3$ & $930-950$ & $20-30$ & $30-40$ & $13-20$ \\
\hline PMMA & - & - & $1,8-3,3$ & 1190 & $35-70$ & $38-80$ & $19-39$ \\
\hline \multicolumn{8}{|l|}{ Ceramics $^{[10,12,13]}$} \\
\hline $\mathrm{Al}_{2} \mathrm{O}_{3}$ & - & - & $366-380$ & 3990 & - & $\begin{array}{c}310-350 \\
3790-4500^{*}\end{array}$ & - \\
\hline $\mathrm{ZrO}_{2}$ & - & - & $150-201$ & 5680 & - & $\begin{array}{c}200-500 \\
2000-7500^{*}\end{array}$ & - \\
\hline \multicolumn{8}{|c|}{ Metals and alloys approved for medical use $2,3[4,7,10,12,14-16]$} \\
\hline \multicolumn{8}{|c|}{ Stainless steel } \\
\hline Fe-18Cr-14Ni-2.5Mo & F138 & $5832-1$ & $190-230$ & 7800 & $170-1213$ & $465-1351$ & $180-820$ \\
\hline \multicolumn{8}{|l|}{ Cobalt alloys } \\
\hline Co-28Cr-6Mo & $\begin{array}{c}\text { F75 } \\
\text { F799 } \\
\text { F1537 } \\
\end{array}$ & $5832-4$ & \multirow{3}{*}{$200-541$} & \multirow{3}{*}{8900} & \multirow{3}{*}{$241-2000$} & \multirow{3}{*}{$430-2068$} & \multirow{3}{*}{$200-1220$} \\
\hline $\begin{array}{l}\text { Co-20Cr-15W-10Ni- } \\
-1.5 \mathrm{Mn}\end{array}$ & F90 & $5832-5$ & & & & & \\
\hline Co-35Ni-20Cr-10Mo & F562 & $5832-6$ & & & & & \\
\hline \multicolumn{8}{|l|}{ Titanium alloys } \\
\hline $\begin{array}{l}\text { Commercially Pure Ti } \\
\text { (Grade 1-4) }\end{array}$ & F67 & $5832-2$ & \multirow{10}{*}{$50-121$} & \multirow{10}{*}{4500} & \multirow{10}{*}{$480-1060$} & \multirow{10}{*}{$240-1312$} & \multirow{10}{*}{$300-689$} \\
\hline \multirow{2}{*}{ Ti-6Al-4V } & F136 & \multirow{2}{*}{$5832-3$} & & & & & \\
\hline & F1472 & & & & & & \\
\hline Ti-6Al-7Nb & F1295 & $5832-11$ & & & & & \\
\hline Ti-15Mo-5Zr-3Al & - & $5832-14$ & & & & & \\
\hline Ti-13Nb-13Zr & F1713 & - & & & & & \\
\hline Ti-12Mo-6Zr-2Fe & F1813 & - & & & & & \\
\hline Ti-15Mo & F2066 & - & & & & & \\
\hline $\mathrm{Ti}-45 \mathrm{Nb}$ & AMS4982 & - & & & & & \\
\hline $\mathrm{Ti}-55 \mathrm{Ni}$ & F2063 & - & & & & & \\
\hline
\end{tabular}

NOTE 1 - tensile properties unless otherwise specified

2 - the intervals of the physical and mechanical properties correspond to values can be obtained by means of various thermomechanical treatment

3 - density $(\rho)$ is given for pure metals $(\mathrm{Fe}, \mathrm{Co}, \mathrm{Ti})$

* - compression properties

$\mathrm{E}$ - the modulus of elasticity; $\sigma_{0,2}$ - the yield strength; $\sigma_{\mathrm{B}}$ - the ultimate strength; $\sigma_{-1}-$ the fatigue limit

alloys and a number of titanium alloys used in medicine are, firstly, alloying chemical elements (Al, V, Ni, Co, Cr) that causing adverse reactions from the living organism; secondly, the existing discrepancy between the implant and the surrounding bone tissue due to the difference in the elastic modulus of the bone and the metal implant $[8$, 16].

Research into the development of metal medical materials have been aimed at solving these problems in the last two decades. One of the approaches is the development of new titanium alloys that do not contain chemical elements causing toxic and allergic reactions of the organism, based on molecular-orbital calculations of electron structures, followed by the creation of special structural-phase states by means of heat and deformation treatments, which allow obtaining lower values of elastic modulus (90...42
GPa) [8, 17-20]. However, numerous studies [8, 1720] have shown that the reduction of the elastic modulus by the methods of alloying and structure formation is limited to a value of at least $40 \mathrm{GPa}$, which is still too high for the bone implant (see Table 2).

Further reduction of the elastic modulus while maintaining acceptable strength characteristics clearly should be associated with the switchover to the use of porous (mesh, foam-like) product structures obtained by powder metallurgy methods [21, 22] or layer-bylayer laser melting / selective laser melting ("3D printing") [23] instead of solid materials. Porous titanium and its alloys ensure the flow of body fluids and bone tissue ingrowth at a pore size of 200-500 $\mu \mathrm{m}$ [24], whereas a reduction in size to $100 \mu \mathrm{m}$ makes osteoblast ingrowth impossible [25]. In addition, the size, shape, pores fraction and their distribution in the 
Table 2. Compositions, processing and elastic modulus of new $\beta$-type Ti alloys [8]

\begin{tabular}{|c|c|c|}
\hline Alloy composition, wt. $\%$ & Production methods / processing & E, GPa \\
\hline Ti-29Nb-13Ta-4Mo & \multirow{4}{*}{ Melting/Solutionized / Aged } & $50-80$ \\
\hline Ti-29Nb-13Ta-6Sn & & $65-70$ \\
\hline Ti-29Nb-13Ta-4.6Sn & & $55-78$ \\
\hline Ti-29Nb-13Ta-2Sn & & $45-48$ \\
\hline Ti-30Nb-10Ta-5Zr & Sintering / Hot-forging and swaging / Heat treatment & 66.9 \\
\hline Ti-35Nb-4Sn & Melting / Cold rolling / Heat treatment & $42-55$ \\
\hline Ti-30Zr-3Cr-3Mo & Solution treated/Cold rolling & $66 / 78$ \\
\hline $\mathrm{Ti}-12 \mathrm{Mo}-3 \mathrm{Nb}$ & Melting / Solution treated & 105 \\
\hline Ti-12Mo-5Ta & Annealed & 74 \\
\hline Ti-50Ta & Solution treated / Aged & $77 / 88 / 93$ \\
\hline Ti-50Ta & \multirow{2}{*}{ Solution treated } & 88 \\
\hline Ti-30Zr- $(5,6,7) \mathrm{Mo}$ & & $75 / 63 / 66$ \\
\hline Ti-30Zr- $(5,6,7) \mathrm{Mo}$ & Cold rolling & $59 / 61 / 73$ \\
\hline Ti-36Nb-2.2Ta-3.7Zr-0.3O (at. \%) & High pressure torsion & $43-65$ \\
\hline Ti-31Fe-9Sn & \multirow{2}{*}{ Cast } & 147 \\
\hline Ti-39.3Nb-13.3Zr-10.7Ta & & 71 \\
\hline Ti-25Nb-11Sn & Swaged & 53 \\
\hline Ti-12Mo-5Zr & Solution treated & 64 \\
\hline Ti-25Nb-2Mo-4Sn & Cold rolling / Aging & 65 \\
\hline
\end{tabular}

material have a significant effect on the complex of physical and mechanical properties. Thus, obtained in [24] titanium with a porosity of $78 \%$ had a compressive strength of $35 \mathrm{MPa}$ with elastic modulus of $5.3 \mathrm{GPa}$, which is close to the characteristics of the bone. On the other hand, the introduction of macroand micropores into material reduces the level of strength characteristics. Therefore, it is essential to take into account many factors, from the pore size to the microstructure of the alloy, when creating a porous titanium material for orthopedics [8].

Various methods are developed to predict mechanical performance of porous materials. Analytical models like proposed by Gibson and Ashby [26] used idealized conditions or simplified assumptions, while the finite element models are able to consider more realistic structures like material with random pores distribution [27].

Due to titanium high melting point and and extreme chemical affinity with atmospheric gases, methods of solid-state powder metallurgy were most widely used to create porous Ti-based materials (while the liquid state techniques are common in production of porous aluminium, zinc and magnesium). Some of the most recently used are partial (loose) sintering of metal powders [28], space holder method [20], spark plasma sintering (porous Ti with yield strength 27.2-94.2 $\mathrm{MPa}$ and elastic modulus 6.2-36.1 GPa was derived in [29]), microwave sintering (Ti-6Al-4V/multiwall carbon nanotubes composite with porosity of approximately $25 \%$, yield strength of $145.48 \pm 27.28 \mathrm{MPa}$ and elastic modulus of $10.87 \pm 2.46 \mathrm{GPa}$ obtained in [30]), combustion synthesis [31], selective laser melting (porous Ti-10Mo alloy with compressive yield strength of $95.59 \mathrm{MPa}$ and an elastic modulus of
4.89 GPa was created in [23]). "3D printing" techniques seems to be most promising among them, since they allow the formation of desired porous structure along with exact implant shape according to the CAD model based on tomography data.

\section{Conclusion}

Thereby, it can be concluded that among the metal materials for orthopedic use, titanium-based alloys are of particular interest due to their high specific strength and biocompatibility; and the modeling and creation of porous titanium implants to replace bone defects (augments) is a promising direction in the development of new metallic materials for medical purposes, as this

allows us to bring the physical-mechanical characteristics of the augment closer to those of the bone tissue.

We hereby acknowledge the support of the Ministry of Science and Education of the Russian Federation, in accordance to the decree of the Government of April 9, 2010, №218, project number 03.G25.31.0234.

\section{References}

1. L.L. Hench, J.M. Polak, Science, 295, 1014-1017 (2002)

2. S.K. Bhullar, N.L. Lala, S. Ramkrishna, Rev. Adv. Mater. Sci., 40, 303-314 (2015)

3. F. Mahyudin, L. Widhiyanto, H. Hermawan, Advanced Structured Materials, 58, 161-181 (2016) 
4. M. Navarro, A. Michiardi, O. Castaño, J.A. Planell, J. R. Soc. Interface, 5, 1137-1158 (2008)

5. F.A. Rodriguez-Gonzalez, Biomaterials in Orthopedic Surgery (ASM International, Materials Park, OH, 2009).

6. L.E. Claes. Clinical Materials, 10, 41-46 (1992)

7. S.R. Golish, W.M. Mihalko, J Bone Joint Surg Am., 93(2), 206-212 (2011)

8. Y. Li, C. Yang, H. Zhao, S.Qu, X. Li, Y. Li., Materials, 7(3), 1709-1800 (2014)

9. I.A. Khlusov, V.P. Pichugin, M.A. Ryabtseva, Basics of biomechanics of biocompatible materials and biological tissues (Tomsk Polytechnic University 2007)

10. B.D. Ratner, A.S. Hoffman, F.J. Schoen, J.E. Lemons, Biomaterials science: an introduction to materials in medicine (Boston: Elsevier, 2013).

11. J.D. Currey, Proc. Inst. Mech. Eng., H. 212(6), 399-412 (1998)

12. N.R. Patel, P.P. Gohil, Int J Emerging Technol Adv Eng. 2(4), 91-101 (2012)

13. Z. Sheikh, S. Najeeb, Z. Khurshid, V. Verma, H. Rashid, M. Glogauer, Materials, 8(9), 5744-5794 (2015).

14. D.C. Hansen, The Electrochemical Society Interface, 17(2), 31-14 (2008).

15. H. Hermawan, D. Ramdan, J. R. P. Djuansjah, Biomedical Engineering - From Theory to Applications (R. Fazel-Rezai, Ed., chapter 17, InTech, Rijeka, Croatia, 2011).

16. M.Yu. Kollerov, V.S. Spektor, S.V. Skvortsova, A.M. Mamonov, D.E. Gusev, G.V. Gurtovaya, Titanium, 2, 42-53 (2015).

17. M. Abdel-Hady, K. Hinoshita, M. Morinaga, Scripta Mater, 55, 476-480 (2006)

18. M. Abdel-Hady Gepreel, M. Niinomi, Journal of the mechanical behavior of biomedical materials, 20, 407-415 (2013)

19. P. Laheurte, F. Prima, A. Eberhardt, Journal of the mechanical behavior of biomedical materials, 3, 566-573 (2010)

20. M. Niinomi, Y. Liu, M. Nakai, H. Liu, H. Li. Regen Biomater, 3(3), 173-185 (2016)

21. H. Nakajima, T. Ikeda, S.K. Hyun, Advanced Engineering Materials, 6(6), 377-384 (2004)

22. C.E Wen, M. Mabuchi, Y. Yamada, K. Shimojima, Y. Chino, T. Asahina, Journal of Materials Science: Materials in Medicine, 13 (4), 397-401 (2002)

23. F.X. Xie, X.B. He, S.L. Cao, X. Lu, X.H. Qu., Corros. Sci., 67, 217-224 (2013)

24. C.E. Wen, M. Mabuchi, Y. Yamada, K. Shimojima, Y. Chino, T. Asahina, Scr. Mater. 45(10), 1147-1153 (2001)

25. W. Xue, B.V. Krishna, A. Bandyopadhyay, S. Bose., Acta Biomater, 3(6), 1007-1018 (2007)
26. L.J. Gibson, M.F. Ashby, Cellular Solids: Structure and Properties (Cambridge University Press: Cambridge, UK, 1997)

27. A.P. Roberts, E.J. Garboczi, Acta Mater, 49, 189197 (2001)

28. I.H. Oh, N. Nomura, N. Masahashi, S. Hanada, Scr. Mater, 49, 1197-1202 (2003)

29. F.M. Zhang, E. Otterstein, E. Burkel. Adv. Eng. Mater, 12, 863-872 (2010)

30. C.Y. Tang, C.T. Wong, L.N. Zhang, M.T. Choy, T.W. Chow, K.C. Chan, T.M. Yue, Q. Chen, J. Alloy, Compd., 557, 67-72 (2013)

31. B.Y. Li, L.J. Rong, Y.Y. Li, V.E. Gjunter, Intermetallics, 8, 881-884 (2000) 